\title{
Ulam-Hyers stability of fixed point equations for singlevalued operators on $K S T$ spaces
}

\section{LILIANA GURAN}

\section{ABSTRACT.}

In this paper we define the notions of Ulam-Hyers stability with respect to a $w$-distance (in the sense of Kada, Suzuki and Takahashi) and prove several Ulam-Hyers stability results for operators satisfying to a contractive-type condition with respect to $w$.

DEPARTMENT OF ACCOUNTING AND MANAGERIAL INFORMATION SYSTEM

FACULTY OF ECONOMIC SCIENCES

"Titu MAIORESCu" University, Bucharest

E-mail address: gliliana.math@gmail.com 